\title{
Distribution of Paycheck Protection Program Loans to Healthcare Organizations in 2020
}

J Gen Intern Med 37(8):2132-3

DOI: $10.1007 /$ s11606-021-07108-6

(C) Society of General Internal Medicine 2021

\section{INTRODUCTION}

During the coronavirus 2019 pandemic, small healthcare businesses may have been at increased risk for financial strain compared to larger entities due to differences in liquidity and access to capital. ${ }^{1,2}$ Different types of healthcare businesses may have varying capacities to mitigate financial strain depending on income sources, revenue cycles, and operating margins. ${ }^{1,2}$ The US government implemented several economic relief programs for which small healthcare businesses were eligible: the Paycheck Protection Program (PPP), Provider Relief Fund, and Economic Injury Disaster Loan. For all programs, businesses must attest to financial need and may be asked to provide substantiating documentation. Each program used different mechanisms for determining the amount of financial support (payroll costs, revenue, or unmet expenses) and repayment. Thus, each program may have resulted in differing participation and support for different business types.

While governmental and news agencies have reported aggregated program statistics, the distribution of funds among healthcare services has not been well described. Understanding patterns of participation and fund distribution can inform future efforts to support small healthcare businesses during periods of economic distress.

Our objective was to describe the distribution of funds for one program, the PPP, to healthcare organizations. The PPP is a loan program for small businesses to help cover payroll, mortgage interest, rent, and utilities. ${ }^{3}$ Loans are proportional to payroll costs and can be forgiven if applied towards approved expenses and if employment and compensation levels are maintained. We hypothesized that participation in the payroll-based PPP would vary based on workforce sizes and financial buffers (i.e., days cash-onhand, based on prior literature).

\section{METHODS}

We conducted a descriptive, national cross-sectional study of approved PPP loans to small-business healthcare entities from

Received May 16, 2021

Accepted August 19, 2021

Published online September 10, 2021 program start (April 3, 2020) to its 2020 application closing (August 8,2020 ) using publicly available Small Business Administration data. ${ }^{3}$ This study was not human subjects research and did not require institutional review board approval. We followed the Strengthening the Reporting of Observational Studies in Epidemiology guidelines for cross-sectional studies.

A small business is defined as a business entity with fewer than 500 employees or less than industry-benchmarked annual revenue. ${ }^{4}$ We identified healthcare entities by North American Industry Classification System codes submitted by loan applicants. ${ }^{5}$ Each code identifies a sector (i.e., healthcare and social services), subsector (i.e., ambulatory healthcare services), and industry (i.e., offices of dentists). Only entities representing healthcare services-subsector codes 621 (ambulatory healthcare services), 622 (hospitals), and 623 (nursing and residential care facilities) - were included for analysis.

We used Stata SE, version 15 (StataCorp), to generate descriptive statistics.

\section{RESULTS}

In $2020,448,537(8.7 \%)$ of $5,151,699$ PPP loans were to healthcare entities, totaling $\$ 58,123,464,991$ ( $11.1 \%$ of all PPP-loaned dollars) and 5,716,679 reported employees (11.3\% of reported employees by all PPP participants).

Ambulatory services received the most loans $(N=415,222$; 92.6\% of all healthcare PPP loans) and largest proportion of dollars $(\$ 43,931,812,128 ; 75.6 \%$ of all healthcare PPP dollars) (Table 1). Nursing and residential care facilities had the highest median loan amount $(\$ 150,900 ; \mathrm{IQR}[\$ 37,500-\$ 495,300])$ and number of reported employees (22; [5-71]). Hospitals received $1.8 \%$ of all healthcare PPP loans, representing $6.4 \%$ of all healthcare PPP dollars.

\section{DISCUSSION}

Financial support from the PPP to healthcare services totaled nearly $\$ 60$ billion during 2020, representing one in nine PPP-loaned dollars. Entities providing ambulatory care services received the majority of loans and PPP-loaned dollars due to higher absolute volume of participation. Nursing and residential care facilities had the most employees, and prior literature suggests that, on average, businesses of any size in this subsector have less liquidity (median days cash-on-hand of 8 , in contrast to 53 for hospitals) ${ }^{1,2}$, which may explain larger loan asks via the payroll-based PPP. 
Table 1 Percentage of Businesses Receiving Loans, Loan Amounts, and Reported Employees by Small-Business Healthcare Entities that Received Paycheck Protection Program Loans

\begin{tabular}{|c|c|c|c|c|c|}
\hline Healthcare subsector & $\begin{array}{l}\text { Loan } \\
\text { recipients, } \\
N(\%)\end{array}$ & $\begin{array}{l}\text { Total loan amount, US\$ } \\
(\%)\end{array}$ & $\begin{array}{l}\text { Median loan amount } \\
\text { (IQR), US\$ }\end{array}$ & $\begin{array}{l}\text { Total reported } \\
\text { employees, } N \\
\text { (\%) }\end{array}$ & $\begin{array}{l}\text { Median reported } \\
\text { employees, } N \\
\text { (IQR) }\end{array}$ \\
\hline All & $448,537(100)$ & $58,123,464,991(100)$ & $38,832(17,700-95,000)$ & $5,716,679(100)$ & $4(1-10)$ \\
\hline Ambulatory healthcare services & $\begin{array}{l}415,222 \\
(92.6)\end{array}$ & $43,931,812,134$ (75.6) & $36,800(17,083-86,875)$ & $4,126,136(72.2)$ & $4(1-9)$ \\
\hline Physician offices & $\begin{array}{l}127,478 \\
(28.4)\end{array}$ & $17,038,912,610(29.3)$ & $40,700(20,800-100,708)$ & $1,270,083(22.2)$ & $4(1-9)$ \\
\hline Dental offices & $\begin{array}{l}101,062 \\
(22.5)\end{array}$ & $8,212,248,545(14.1)$ & $58,639(30,000-96,112)$ & $717,869(12.6)$ & $6(3-9)$ \\
\hline $\begin{array}{l}\text { Other healthcare professional } \\
\text { offices* }\end{array}$ & $\begin{array}{l}124,341 \\
(27.7)\end{array}$ & $6,625,510,912(11.4)$ & $20,347(9,257-44,350)$ & $666,563(11.7)$ & $2(1-5)$ \\
\hline $\begin{array}{l}\text { Laboratory and diagnostic } \\
\text { services }\end{array}$ & $6,144(1.4)$ & $1,256,397,600(2.2)$ & $47,500(20,200-149,730)$ & $95,058(1.7)$ & $5(1-13)$ \\
\hline Home health care services & $25,070(5.6)$ & $5,321,270,981(9.2)$ & $54,979(16,108-190,000)$ & $847,644(14.8)$ & $9(1-36)$ \\
\hline $\begin{array}{l}\text { All other ambulatory healthcare } \\
\text { services }\end{array}$ & $31,127(6.9)$ & $5,477,471,480(9.4)$ & $37,215(14,770-119,600)$ & $528,919(9.3)$ & $4(1-14)$ \\
\hline Hospitals $^{\S}$ & $8,143(1.8)$ & $3,711,570,682(6.4)$ & $47,865(20,800-235,200)$ & $308,028(5.4)$ & $5(1-20)$ \\
\hline $\begin{array}{l}\text { Nursing and residential care } \\
\text { facilities }\end{array}$ & $25,172(5.6)$ & $10,480,082,180(18.0)$ & $\begin{array}{l}150,900(37,500- \\
495,300)\end{array}$ & $1,282,515(22.4)$ & $22(5-71)$ \\
\hline Skilled nursing facilities & $9,868(2.2)$ & $5,507,652,920(9.5)$ & $\begin{array}{l}324,825(67,626- \\
751,650)\end{array}$ & $656,151(11.5)$ & $46(8-101)$ \\
\hline $\begin{array}{l}\text { Residential care facilities } \\
\text { Retirement and assisted living } \\
\text { facilities }^{\text {It }}\end{array}$ & $\begin{array}{l}6,588(1.5) \\
8,716(1.9)\end{array}$ & $\begin{array}{l}2,276,476,883(3.9) \\
2,695,952,378(4.6)\end{array}$ & $\begin{array}{l}80,204(25,000-304,325) \\
115,646(35,000- \\
308,800)\end{array}$ & $\begin{array}{l}267,779(4.7) \\
358,585(6.3)\end{array}$ & $\begin{array}{l}12(3-42) \\
19(5-50)\end{array}$ \\
\hline
\end{tabular}

*Offices of chiropractors; offices of optometrists; offices of mental health practitioners (except physicians); offices of physical, occupational and speech therapists and audiologists; offices of podiatrists; offices of all other miscellaneous health practitioners

† Medical laboratories; diagnostic imaging centers; blood and organ banks

$\$$ Family planning centers; outpatient mental health and substance abuse centers; health maintenance organization medical centers; kidney dialysis centers; freestanding ambulatory surgical and emergency centers; all other outpatient care centers; ambulance services; all other miscellaneous ambulatory health care services

${ }^{s}$ General medical and surgical hospitals; psychiatric and substance abuse hospitals; specialty (except psychiatric and substance abuse) hospitals

"Residential intellectual and developmental disability facilities; residential mental health and substance abuse facilities; other residential care facilities

${ }^{\text {" }}$ Continuing care retirement communities; assisted living facilities for the elderly

There are important limitations to consider. Not all eligible entities may have been aware of the PPP or chose to participate; thus, fund distribution may be more reflective of awareness and relationships with lending agencies than market demand. We do not report on relative participation between subsectors or industries because information on the total potentially eligible businesses in each category was not available. Finally, data are self-reported by applicants.

Future studies may describe distribution of other support program funds to understand which mechanisms of funding garner the most participation from and support to different types of healthcare organizations.

Kevin Chen, $M D, M_{H}^{1,2}$

Leo Lopez, MD, MHS ${ }^{1,3}$

Joseph S. Ross, MD, MHS ${ }^{4}$

Jasmine L. Travers, $\mathrm{PhD}, \mathrm{MHS}^{5}$

${ }^{1}$ Office of Ambulatory Care and Population Health,

New York City Health and Hospitals,

, NY 10004New York, USA

${ }^{2}$ Department of Medicine, New York University

Grossman School of Medicine,

New York, NY, USA

${ }^{3}$ Department of Population Health, New York

University Grossman School of Medicine,

New York, NY, USA
${ }^{4}$ Department of Medicine, Yale University School of Medicine,

New Haven, CT, USA

${ }^{5}$ New York University Rory Meyers College of Nursing, New York, NY, USA

Corresponding Author: Kevin Chen, MD, MHS; Office of Ambulatory Care and Population Health, New York City Health and Hospitals, , NY 10004New York, USA (e-mail: research@kchenmd.com).

\section{REFERENCES}

1. Khullar D, Bond AM, Schpero WL. COVID-19 and the Financial Health of US Hospitals. JAMA. 2020;323(21):2127-2128.

2. Begley TA, Weagley D. Firm Finances and the Spread of COVID-19: Evidence from Nursing Homes. Georgia Tech Scheller College of Business; 2021 Jun 30. 51p. Research Paper No.: 3659480.

3. U.S. Small Business Administration. Paycheck Protection Program https://www.sba.gov/funding-programs/loans/coronavirus-relief-options/paycheck-protection-program. Accessed 22 Feb 2021.

4. Code of Federal Regulations. Size Standards Used to Define Small Business Concerns. https://www.ecfr.gov/cgi-bin/text-idx? SID=b919ec8f32 159d9edaaa36a7eaf6b695\&mc=true \&node=pt13.1. 121\&rgn=div5\#se13.1.121_1201. Accessed 22 Feb 2021.

5. Office of Management and Budget, Executive Office of the President. North American Industry Classification System, United States, 2017. https:// www.census.gov/eos/www/naics/2017NAICS/2017_NAICS_Manual.pdf. Accessed 22 Feb 2021.

Publisher's Note: Springer Nature remains neutral with regard to jurisdictional claims in published maps and institutional affiliations. 